\title{
PENGARUH CITRA MEREK DAN KUALITAS PRODUK TERHADAP MINAT BELI KONSUMEN PRODUK SMARTPHONE XIAOMI (STUDI KASUS DI JAKARTA BARAT)
}

\author{
Hermanto $^{1)^{*}}$, Rendy Saputra ${ }^{2)}$ \\ 1,2 Universitas Esa Unggul \\ Diterima 26-9-2018 / Disetujui 3-3-2019
}

\begin{abstract}
The existence of a decrease in product sales Smartphone Xiaomi significant gains from the year 2015-2016, due to Intense competition in the telecommunications business are on the rise. This research aims to know the influence of the brand image and product quality against the interest of the consumer to buy the product in the region of Xiaomi Smartphone West Jakarta taken Samples as many 100 respondents. The method used is the quantitative methods based on the results of interviews and questionnaires for testing instrument using the test validity, and reliability. Data analysis techniques using multiple linear regression due to variables that are used more than two variables, with the t-test and F-test. The research results showed that the t-test with a brand image partially effect significantly to interest consumers buy Smartphone Xiaomi. While the quality of the product partially do not affect significantly to interest consumers buy Smartphone Xiaomi. F test results show that simultaneously the brand image and product quality significantly to influential interests buy consumer products Smartphone Xiaomi. And brand image is the most influential variables are dominant against the interest of the consumer to buy the product of Xiaomi Smartphone on the quality of the product.
\end{abstract}

Keywords: Brand Image, Product Quality and Interest To Buy.

\begin{abstract}
ABSTRAK
Adanya penurunan penjualan produk Smartphone Xiaomi yang cukup signifikan dari tahun 2015 -2016, yang disebabkan ketatnya persaingan usaha dalam bidang telekomunikasi yang terus meningkat. Penelitian ini bertujuan untuk mengetahui pengaruh citra merekdan kualitas produk terhadap minat beli konsumen produk Smartphone Xiaomi di wilayah Jakarta Barat yang diambil sampelnya sebanyak 100 responden. Metode yang digunakan adalah metode kuantitatif berdasarkan hasil wawancara dan kuesioner untuk pengujian instrument menggunakan uji Validitas, dan Reliabilitas. Teknik analisis data menggunakan regresi linear berganda karena variabel yang digunakan lebih dari dua variabel, dengan uji t dan ujif. Hasil penelitian dengan uji t menunjukkan bahwa citra merek secara parsial berpengaruh signifikan terhadap minat beli konsumen produk Smartphone Xiaomi. Sedangkan kualitas produk secara parsial tidak berpengaruh signifikan terhadap minat beli konsumen Smartphone Xiaomi. Hasil uji F menunjukkan bahwa secara simultan citra merek dan kualitas produk berpengaruh signifikan terhadap minat beli konsumen produk Smartphone Xiaomi, dan citra merek adalah variabel yang paling berpengaruh dominan terhadap minat beli konsumen produk Smartphone Xiaomi daripada kualitas produk.
\end{abstract}

Kata Kunci: Citra Merek, Kualitas Produk dan Minat Beli. 


\section{PENDAHULUAN}

Perkembangan jumlah penduduk yang cukup pesat serta beragamnya aktivitas yang dilakukan manusia memungkinkan segala aktivitas tersebut harus dilakukan dengan cepat dan efesien.Hal tersebut memiliki tujuan agar manusia dapat melakukan pekerjaan dengan cepat dan efesien, manusia sangat membutuhkan sarana pendukung yang membantu pekerjaan tersebut, seperti alat komunikasi (gadget). Kebutuhan akan alat komunikasi (gadget) pada dewasa ini telah menjadi kebutuhan primer yang tidak dapat terlepaskan dari kehidupan manusia, khususnya pada perangkat smartphone (telepon cerdas). Telepon cerdas (smartphone) adalah telepon genggam yang mempunyai kemampuan tingkat tinggi dengan fungsi yang menyerupai komputer.

Sebelum smartphone dikenal luas, awalnya terdapat dua alat komunikasi dengan produk berbeda yaitu handphone dan Personal Digital Assistant (PDA). Smartphone dilengkapi dengan berbagai pilihan fitur seperti bisa menangkap frekuensi siaran radio dan televisi, perangkat lunak pemutar audio (MP3), video, camera digital, game, layanan internet, email, media sosial dan perangkat editing document microsoft office. Di Indonesia terdapat beragam merek smartphone yang bersaing dalam dunia bisnis di Indonesia antara lain : Apple, Xiaomi, Huawei, Samsung, Lenovo, Oppo, Vivo dan sebagainya. Dalam keadaan seperti ini menyebabkan persaingan yang sangat ketat dalam industri smartphone.

Berdasarkan gambar Top Vendor Market Share di bawah ini memperlihatkan beberapa produk unggulan smartphone yang mengalami penurunan khususnya merek Xiaomi, dapat dilihat dalam gambar berikut :

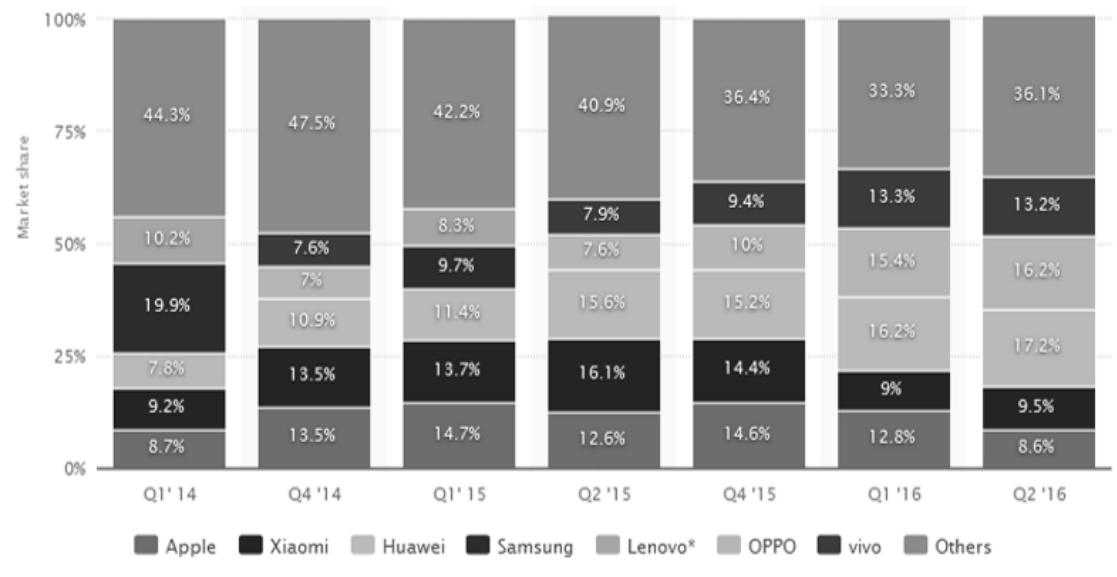

Gambar 1 Top Vendor Market Share 2014 - 2016

Sumber : Statista.com, 2016

Berdasarkan gambar 1 diatas, pada Quartal 2 tahun 2015 Xiaomi tercatat sebagai merek produk dengan Market Share tertinggi sebesar 16,1\% dan pada Quartal 1 tahun 2016 produk Xiaomi mengalami penurunan sebesar $9 \%$ dan sempat mengalami kenaikan pada Quartal 2 tahun 2016 sebesar 5\%. Hal tersebut terjadi karena semakin banyaknya persaingan dari berbagai merek smartphone lain seperti Apple, Huawei, Samsung, Lenovo,
Oppo, Vivo, dan lain-lain yang beredar dipasaran.

Untuk melengkapi data penelitian, peneliti melakukan prasurvey mengenai citra merek dan kualitas produk kepada pengguna smartphone terutama smartphone dengan merek Xiaomi, dengan melakukan penyebaran angket atau kuesioner kepada 15 responden yang menggunakan smartphone Xiaomi. Hasil dari penyebaran kuesioner dapat dilihat sebagai berikut: 
Tabel 1. Pertimbangan Memilih Smartphone

\begin{tabular}{|c|c|c|c|c|}
\hline \multirow{2}{*}{ Pertanyaan } & \multicolumn{3}{|c|}{ Jawaban Responden } & \multirow{2}{*}{$\begin{array}{c}\text { Total } \\
\text { Persentase }\end{array}$} \\
\cline { 2 - 5 } & Ya & Ragu-ragu & Tidak & $33 \%$ \\
\hline Berdasarkan Merek & 5 & - & - & $67 \%$ \\
\hline $\begin{array}{c}\text { Berdasarkan Kualitas } \\
\text { Produk }\end{array}$ & 10 & - & - & $73 \%$ \\
\hline $\begin{array}{c}\text { Berminat Membeli } \\
\text { Produk terbaru xiaomi }\end{array}$ & 11 & 2 & 2 & $73 \%$ \\
\hline
\end{tabular}

Sumber : Hasil Olahan Data Peneliti, 2016

Berdasarkan hasil pra survey pada yang dilakukan pada tahun 2016 dalam bentuk tabel diatas, hasilnya menunjukkan bahwa sebanyak 33\% (5 responden) menggunakan produk Xiaomi berdasarkan merek dagang, 67\% (10 responden) menggunakan produk xiaomi berdasarkan kualitas yang dapat dirasakannya. Dari 15 responden tersebut, 73\% (11 responden) berminat melakukan pembelian terhadap produk Xiaomi terbaru, sedangkan $13 \%$ (2 responden) mengatakan ragu-ragu dan $13 \% \quad(2$ responden $)$ mengatakan tidak berminat terhadap produk terbaru Xiaomi.

Dari data tersebut terlihat bahwa produk smartphone Xiaomi memiliki peminat yang cukup tinggi dibanding dengan merekmerek smartphone lainnya. Dalam hal ini menyadari pentingnya sebuah citra merek dan kualitas produk di dalam peningkatan minat beli konsumen. hal tersebut menjadi menarik bagi peneliti untuk mengkaji dua variabel independen tersebut dan mengkaji pengaruh terhadap minat konsumen suatu produk.

\section{Citra Merek}

Menurut Rangkuti (2004) citra dibentuk dari persepsi yang dimiliki oleh masing-masing individu terhadap merek dan perusahaan yang bersangkutan. Ada sebuah citra yang disebut dengan citra merek yaitu seperangkat keyakinan konsumen mengenai merek tertentu. Sebuah merek membutuhkan citra untuk mengkomunikasikan kepada khalayak tentang nilai-nilai yang terkandung di dalamnya. Sedangkan menurut Sutojo (2004) citra adalah pancaran atau reproduksi jati diri dari atau bentuk orang-perorangan, benda, atau organisasi. Image (citra) juga dapat diartikan sebagai persepsi masyarakat terhadap jati diri perusahaan.

Undang-undang RI nomor 15 Tahun 2001 tentang merek, menyatakan bahwa merek adalah tanda yang berupa gambar, nama, kata, huruf-huruf, angka-angka, susunan warna, atau kombinasi dari unsurunsur tersebut yang memiliki daya pembedaan dan digunakan dalam kegiatan perdagangan barang atau jasa (Sunyoto, 2012). Merek merupakan salah satu komponen utama dalam suatu produk, strategi suatu merek yang sudah dikenal bisa menyebabkan harga menjadi tinggi. Namun dalam rangka menciptakan suatu produk atau jasa yang bermerek memerlukan proses dan investasi jangka panjang terutama dalam hal iklan (advertising), promosi (promotion), dan pengemasan (packaging). Merek memerlukan proses dan investasi jangka panjang terutama dalam hal iklan (advertising), promosi (promotion), dan pengemasan (packaging). Merek merupakan sesuatu yang dibeli oleh kosumen, memiliki nilai dan identitas atau ciri tertentu yang dilindungi secara hukum sehingga tidak dapat ditiru oleh pesaing (Tjiptono, 2011).

Menurut Setiadi (2003) brand image (citra merek) mempresentasikan keseluruhan persepsi terhadap merek dan dibentuk dari informasi dan pengalaman masa lalu terhadap merek itu. Citra terhadap suatu merek berhubungan dengan sikap yang berupa keyakinan dan preferensi terhadap suatu merek. Menurut Shimp (2000) citra merek dapat dianggap sebagai jenis assosiasi yang muncul dibenak konsumen ketika mengingat sebuah merek tertentu. Assosiasi tersebut secara sederhana dapat muncul dalam bentuk 
pemikiran atau citra tertentu yang dikaitkan kepada suatu merek, sama halnya ketika kita berpikir mengenai orang lain.

\section{Kualitas Produk}

Menurut Oentoro (2012) kualitas produk adalah ukuran tahan lamanya produk itu, dapat dipercayainya produk tersebut, ketetapan (precition) produk, mudah mengoperasikannya dan memeliharanya, serta atribut lain. Dari segi pandang pemasaran, kualitas diukur dalam ukuran persepsi pembeli tentang mutu atau kualitas produk tersebut. Kebanyakan produk disediakan atau diadakan mulanya berawal pada satu diantara empat tingkatan kualitas yang berkualitas, yaitu kualitas rendah, kualitas rata-rata (sedang), kualitas baik (tinggi), dan kualitas sangat baik.

\section{Minat Beli}

Menurut Oentoro (2012) minat beli konsumen adalah inisiatif responden dalam pengambilan keputusan untuk membeli sebuah produk. Model terperinci perilaku konsumen tersebut menjelaskan bahwa rangsangan pemasaran yang terdiri dari variabel marketing mix yaitu produk, harga, tempat, dan promosi sebagai komponen utama dalam pemasaran. Komponen utama tersebut juga dipengaruhi oleh adanya rangsangan lainnya yaitu bersifat eksternal yaitu ekonomi, teknologi, politik dan budaya.

Sedangkan menurut Suyanto (2007) kualitas produk adalah seberapa baik sebuah pokok sesuai dengan kebutuhan spesifik dari pelanggan. Kualitas meliputi kualitas kinerja, kualitas kesesuaian, daya tahan, dan keandalan. Kualitas kinerja mengacu pada tingkat dimana karakteristik produk itu beropersi. Kualitas kesesuaian merupakan tingkat dimana semua unit yang diproduksi memenuhi spesifikasi sasaran yang diharapkan pada kondisi normal atau berat. Adapun keandalan merupakan suatu produk tidak akan rusak atau gagal dalam waktu periode.

\section{Hubungan antara Citra Merek dengan Minat Beli}

Brand image (citra merek) menurut Tjiptono (2011) adalah deskripsi tentang asosiasi dan keyakinan konsumen terhadap merek tertentu. Brand Image itu sendiri memiliki arti kepada suatu pencitraan yang sama terhadap sebuah merek. Sehingga pembentukan citra positif akan suatu merek akan menjadi salah satu tolak ukur penilaian konsumen dalam melihat sebuah produk atau layanan jasa.

Minat konsumen adalah seberapa besar kemungkinan konsumen membeli suatu merek atau seberapa mungkin konsumen untuk berpindah dari suatu merek ke merek lainnya (Yoestini, 2012). Hal ini membuat minat beli sangat cocok menjadi variabel dependen yang dipengaruhi oleh citra merek. Citra Merek yang positif sangat menentukan kesan terhadap sebuah toko dan motif produk yang sering menjadi latar belakang minat beli konsumen.

$\mathrm{H}_{1}$ : Diduga terdapat pengaruh citra merek terhadap minat beli konsumen pada smartphone Xiaomi.

\section{Hubungan antara Kualitas Produk dengan Minat Beli}

Menurut Wijaya (2011), kualitas produk merupakan hal yang perlu mendapat perhatian utama dari perusahaan atau produsen, mengingat kualitas suatu produk berkaitan erat dengan konsumen, yang merupakan tujuan dari kegiatan pemasaran yang dilakukan perusahaan. Setiap perusahaan atau produsen harus memilih tingkat kualitas yang akan membantu atau menunjang usaha untuk menigkatkan atau mempertahankan posisi produk itu didalam pasar sasarannya. Kualitas merupakan suatu dari alat utama untuk mencapai posisi produk.

Sedangkan menurut Durianto et al. (2003), minat beli adalah keinginan untuk memiliki produk. Minat beli akan timbul apabila seseorang konsumen sudah merasakan kualitas dari suatu produk. Hal ini membuat minat beli sangat cocok menjadi variabel dependen yang dipengaruhi oleh kualitas produk. Dengan adanya persaingan pasar, maka produsen harus dapat meningkatkan kualitas produknya, sehingga hal ini dapat menciptakan minat beli konsumen. 
$\mathrm{H}_{2}$ : Diduga terdapat pengaruh kualitas produk terhadap minat beli konsumen pada smartphone Xiaomi.

$\mathrm{H}_{3}$ : Diduga terdapat pengaruh simultan citra merek dan kualitas produk terhadap minat beli konsumen pada smartphone Xiaomi.

$\mathrm{H}_{4}$ : Diduga variabel citra merek dan kualitas produk berpengaruh dominan terhadap minat beli konsumen pada smartphone Xiaomi.

\section{METODE PENELITIAN}

\section{Populasi, Sampel dan Penarikan Sampel}

Dalam penelitian ini yang menjadi populasi sampel penelitian adalah seluruh masyarakat di Wilayah DKI Jakarta, khususnya wilayah Jakarta Barat. Metode pengambilan sampel dalam penelitian ini menggunakan quota sampling. Dikarenakan jumlah populasi dalam penelitian ini tidak diketahui namun memiliki karakteristik yang homogen atau sejenis, maka peneliti menetapkan jumlah sampel sebanyak 100 responden. Dimana responden yang dipilih berdasarkan kriteria sebagai berikut :

1. Memiliki Pekerjaan tetap.

2. Memiliki penghasilan sebulan minimal UMR sebesar Rp.3.100.000.-

3. Pernah menggunakan smartphone Xiaomi tipe apa saja minimal 3 bulan.

\section{Analisis Data}

Sasaran dari penelitian ini adalah untuk melihat pengaruh suatu variabel terhadap variabel lainnya melalui pendekatan metode kuantitatif. Dalam melakukan analisa data di penelitian ini, Peneliti menggunakan metode analisis regresi linear berganda. Persamaan regresi akan terlihat seperti dibawah ini :

$$
\mathbf{Y}=\mathbf{a}+\boldsymbol{\beta}_{1} \mathbf{X}_{1}+\boldsymbol{\beta}_{2} \mathbf{X}_{2}+\mathbf{e}
$$

Dimana :

$X=$ Nilai sebenarnya suatu kasus data. $\beta=$ Nilai yang mewakili koefisien regres baku (standardized) dan koefisien regresi tidak baku (unstandardized). Koefisien regresi ini merupakan jumlah perubahan yang terjadi pada $\mathrm{Y}$ yang disebabkan oleh perubahan nilai $X$.

$\mathrm{a}=$ merupakan intercept yang merupakan nilai Y saat nilai predictor sebesar nol.

\section{Uji Parsial (uji t)}

Anindita (2009) mengatakan bahwa uji $\mathrm{t}$ digunakan untuk menguji pengaruh secara parsial atau sendiri-sendiri (atau individu) variabel independen mempengaruhi variabel dependen atau tidak.

$t=\frac{b-B}{S b}$

$\mathrm{H}_{0}: \beta \mathrm{i}=0$ (secara parsial, $\mathrm{X}$ tidak mempengaruhi $\mathrm{Y}$ )

Ha : $\beta \mathrm{i} \neq 0$ (secara parsial, $X$ mempengaruhi $\mathrm{Y}$ )

Terima $\mathrm{H}_{0}$, Jika nilai sig $\mathrm{t}>0.05$ atau $-\mathrm{t}$ tabel $<\mathrm{t}$ hitung $<\mathrm{t}$ tabel.

Terima Ha, Jika nilai sig $\mathrm{t}<0.05$ atau $-\mathrm{t}$ tabel $<$ t hitung $>$ t tabel.

\section{Uji Model (uji F)}

Menurut Anindita (2009), uji F digunakan untuk mengetahui apakah model yang digunakan dalam analisa regresi sudah tepat atau belum, dan melihat apakah secara simultan variabel independen mempengaruhi variabel dependen. Dengan rumus sebagai berikut :

$F=\frac{R^{2} /(k-1)}{\left(1-R^{2}\right) /(n-k)}$

$$
\begin{aligned}
& \text { Dimana : } \\
& \mathrm{R}^{2}=\text { Koefisien Determinasi } \\
& \mathrm{K}=\text { Jumlah Variabel } \\
& \mathrm{N}=\text { Jumlah Data } \\
& \mathrm{H}_{0}: \beta_{1}=\beta_{2}=\beta_{3}=\ldots . .=\beta_{1}=0
\end{aligned}
$$

Secara bersama-sama variabel independen tidak mempengaruhi variabeldependen atau model persamaan yang terbentuk belum yang tepat.

$$
\text { Ha : } \beta_{1} \neq \beta_{2} \neq \ldots \ldots=\beta \neq 0
$$


Secara bersama-sama variabel independen mempengaruhi variabel dependen atau model persamaan yang terbentuk sudah tepat.

Terima $\mathrm{H}_{0}$, Jika $\mathrm{F}$ hitung $<\mathrm{F}$ tabel atau nilai sig $\mathrm{F}>0.05$

Terima Ha, Jika $\mathrm{F}$ hitung $>\mathrm{F}$ tabel atau nilai sig $\mathrm{F}<0.05$

\section{Koefisien Determinasi}

Menurut Maholtra (2005), koefisien determinasi pada intinya adalah untuk mengukur seberapa jauh kemampuan model dalam menerangkan variasi variabel dependen. Nilai koefisien determinasi adalah 0 dan 1. Nilai koefisien determinasi yang kecil berarti kemampuan variabel independen dalam menjelaskan variabel dependen sangat terbatas.

$\mathrm{R}=\left(\mathrm{r}^{2}\right) \times 100 \%$

$\mathrm{R}=$ Koefisien Determinasi

$\mathrm{R}=$ Koefisien Korelasi

\section{Definisi Operasional Variabel}

$\begin{array}{crr}\text { Brand image (citra merek) } & \text { mersi }\end{array}$

terhadap merek dan dibentuk dari informasi dan pengalaman masa lalu terhadap merek tersebut. Citra terhadap suatu merek berhubungan dengan sikap yang berupa keyakinan dan preferensi. Kualitas produk merupakan hal yang perlu mendapat perhatian utama dari perusahaan atau produsen smartphone, mengingat kualitas suatu produk berkaitan erat dengan konsumen, yang merupakan tujuan dari kegiatan pemasaran yang dilakukan perusahaan. Minat beli adalah keinginan untuk memiliki produk. Minat beli akan timbul apabila seorang konsumen sudah merasakan kualitas dari suatu produk yang telah digunakannya. Apabila manfaat yang telah dirasakan melebihi eksepstasi pengguna dibandingkan biaya pengorbanan untuk mendapatkan produk tersebut, maka dorongan untuk membeli produk tersebut semakin tinggi.

\section{HASIL DAN PEMBAHASAN}

\section{Hasil Regresi Linear Berganda}

Tabel berikut merupakan hasil output software statistik variabel-variabel penelitian yang diolah oleh peneliti.

Tabel 2. Hasil Pengujian Hipotesis

\begin{tabular}{|c|c|c|}
\hline Variabel & Koefisien Regresi & Sig. \\
\hline (Constant) & 1,757 &, 003 \\
\hline Citra Merek &, 360 &, 000 \\
\hline Kualitas Produk &, 112 &, 460 \\
\hline
\end{tabular}

a. Dependent Variable: Minat Beli

Sumber: Hasil Output Statistik Peneliti, 2017

Berdasarkan hasil output statistik diatas, diperoleh persamaan regresi linear berganda sebagai berikut:

$$
\mathrm{Y}=1,757+0,360 \mathrm{X}_{1}+0,112 \mathrm{X}_{2}
$$

Kesimpulan dari model regresi diatas adalah sebagai berikut:

a. Konsta $\left(\beta_{0}\right)=1,757$ menunjukkan besarnya variabel minat beli yang tidak dipengaruhi oleh variabel citra merek $\left(\mathrm{X}_{1}\right)$, kualitas produk $\left(\mathrm{X}_{2}\right)$ atau variabel bebas $=0$ maka nilai minat beli sebesar 1,757 .

b. Nilai koefisien $\left(\beta_{1}\right)$ sebesar 0,360 menunjukkan bahwa jika variabel citra merek ditingkatkan, maka akan mengakibatkan peningkatan minat beli $\left(\mathrm{X}_{1}\right)$ sebesar 0,360 dengan asumsi 
sisanya dipengaruhi oleh variabel lain diluar penelitian.

c. Nilai koefisien $\left(\beta_{2}\right)$ sebesar 0,112 menunjukkan bahwa jika variabel kualitas produk ditingkatkan, maka akan mengakibatkan peningkatan minat beli $\left(\mathrm{X}_{2}\right)$ sebesar 0,112 dengan asumsi sisanya dipengaruhi oleh variabel lain diluar penelitian. d. $e_{i}$ menunjukkan faktor pengganggu diluar model yang diteliti.

\section{Uji Hipotesis}

\section{Uji Parsial (uji t)}

Uji $t$ digunakan untuk menguji pengaruh secara parsial atau sendiri-sendiri atau individu variabel independen mempengaruhi variabel dependen atau tidak, dengan hasil sebagai berikut:

Tabel 3 Koefisien Regresi

\begin{tabular}{|c|c|c|c|c|}
\hline Variabel & $\begin{array}{c}\text { Nilai Unstandardized } \\
\text { Coefficient B }\end{array}$ & $\mathbf{t}$ Hitung & $\mathbf{t}$ Tabel & Sig. \\
\hline (Constant) & 1,757 & 3,031 & 1,98472 &, 003 \\
\hline Citra Merek &, 360 & 3,71 & 1,98472 &, 000 \\
\hline Kualitas Produk &, 112 & 0,741 & 1,98472 &, 460 \\
\hline
\end{tabular}

a. Dependent Variable: Minat Beli

Sumber: Hasil output statistik peneliti, 2017

Berdasarkan hasil output statistik diatas, diperoleh $\alpha=$ dengan nilai signifikan $0,000<0,05$ atau $\mathrm{t}_{\text {hitung }}=3,710>\mathrm{t}_{\text {tabel }}=$ 1,98472. Maka $\mathrm{H}_{\mathrm{a}}$ diterima dan $\mathrm{H}_{0}$ ditolak dengan tingkat signifikansi 5\%. Artinya secara parsial variabel citra merek $\left(\mathrm{X}_{1}\right)$ berpengaruh dan signifikan terhadap minat beli (Y).

Berdasarkan hasil output statistik tabel 4.9 diatas, diperoleh $\alpha=$ dengan nilai sig $0,460>0,05$ atau $t_{\text {hitung }}=0,741<\mathrm{t}_{\text {tabel }}=$ 1,98472. Maka $\mathrm{H}_{0}$ diterima dan $\mathrm{H}_{\mathrm{a}}$ ditolak dengan tingkat signifikansi 5\%.Artinya secara parsial variabel kualitas produk $\left(\mathrm{X}_{2}\right)$ tidak mempunyai pengaruh signifikan terhadap minat beli (Y).
Berdasarkan hasil output statistik tabel diatas juga mendapatkan hasil penelitian, faktor yang paling berpengaruh dalam minat beli $(\mathrm{Y})$ adalah citra merek $\left(\mathrm{X}_{1}\right)$ dibandingkan dengan kualitas produk $\left(\mathrm{X}_{2}\right)$. Hal ini dibuktikan dengan nilai unstandardized coefficient B yang terbesar yaitu 0,356 dan ada pengaruh yang signifikan sebesar 0,000 .

\section{Uji Model (uji F)}

Uji $\mathrm{F}$ digunakan untuk mengetahui apakah model yang digunakan dalam analisa regresi sudah tepat atau belum, dan melihat apakah secara simultan variabel independen mempengaruhi variabel dependen.

Tabel 4. Nilai F Hitung

\begin{tabular}{|l|c|c|c|}
\hline \multicolumn{1}{|c|}{ Variabel } & F $_{\text {hitung }}$ & F $_{\text {tabel }}$ & Sig. \\
\hline Citra Merek $\left(\mathrm{X}_{1}\right)$ & \multirow{2}{*nn}{8,044} & 3,09 &, $001^{\mathrm{b}}$ \\
\cline { 1 - 2 } Kualitas Produk $\left(\mathrm{X}_{2}\right)$ & & & \\
\hline Minat Beli (Y) & & & \\
\hline
\end{tabular}

Sumber: Hasil Output Statistik Peneliti, 2017

Berdasarkan hasil output diatas, mendapatkan hasil angka $F_{\text {hitung }}=8,044>$ $\mathrm{F}_{\text {tabel }}=3,09$ atau signifikan sebesar $0,001<$
0,05. Maka model regresi dapat digunakan untuk memprediksi minat beli $(\mathrm{Y})$ atau dapat dikatan bahwa $\mathrm{H}_{0}$ ditolak dan $\mathrm{H}_{\mathrm{a}}$ diterima. 
Artinya variabel bebas citra merek $\left(\mathrm{X}_{1}\right)$ dan kualitas produk $\left(\mathrm{X}_{2}\right)$ berpengaruh secara simultan terhadap variabel terikat minat beli (Y).

\section{Koefisien Determinasi}

Koefisien determinasi $\left(\mathrm{R}^{2}\right)$ bertujuan untuk mengetahui seberapa besar kemampuan variabel independen menjelaskan variabel dependen. Dalam hasil uji menggunakan perangkat software statistik memiliki hasil sebagai berikut:

Tabel 5. Nila R Squares

\begin{tabular}{|c|c|}
\hline Variabel & Nilai R Square \\
\hline (Constant) &, 142 \\
\hline Citra Merek & \\
\hline Kualitas Produk & \\
\hline
\end{tabular}

Sumber: Hasil Output Statistik Peneliti, 2017

Berdasarkan hasil output statistik diatas, maka besarnya pengaruh langsung variabel citra merek $\left(\mathrm{X}_{1}\right)$ dan kualitas produk $\left(\mathrm{X}_{2}\right)$ terhadap minat beli $(\mathrm{Y})$ sebesar 0,142 atau $14,2 \%$. Artinya variabel citra merek $\left(\mathrm{X}_{1}\right)$ dan kualitas produk $\left(\mathrm{X}_{2}\right)$ memiliki pengaruh secara langsung terhadap perubahan minat beli (Y) sebesar 14,2\%. Adapun sisa pengaruh sebesar $85,8 \%(100 \%-14,2 \%)$ ditentukan oleh variabel lain diluar penelitian ini.

\section{SIMPULAN}

Berdasarkan hasil yang telah diuraikan diatas, maka dapat ditarik beberapa kesimpulan dari keseluruhan hasil penelitian yaitu sebagai berikut:

1. Hasil pengujian hipotesis secara parsial variabel citra merek terhadap minat beli pada tabel 4.9, menunjukkan $\alpha=$ dengan nilai signifikan $0,000<0,05$ atau $\mathrm{t}_{\text {hitung }}=$ $3,710>\mathrm{t}_{\text {tabel }}=1,98472$. Maka dengan demikian hasil penelitian menunjukkan variabel citra merek berpengaruh signifikan terhadap minat beli.

2. Hasil pengujian hipotesis secara parsial variabel kualitas produk terhadap minat beli pada tabel 4.9 , diperoleh hasil $\alpha=$ dengan nilai sig $0,460>0,05$ atau $t_{\text {hitung }}$ $=0,741<\mathrm{t}_{\text {tabel }}=1,98472$. Maka dengan demikian hasil penelitan menunjukkan variabel kualitas produk memiliki pengaruh terhadap minat beli.

3. Hasil uji model pada tabel 4.10 mendapatkan hasil $\mathrm{F}_{\text {hitung }}=8,044>\mathrm{F}_{\text {tabel }}$
$=3,09$ atau signifikan sebesar $0,001<$ 0,05 . dengan demikian hasi uji model penelitian ini memiliki arti variabel citra merek dan kualitas produk berpengaruh signifikan terhadap minat beli.

4. Hasil dari output statistik menunjukkan variabel yang paling dominan pengaruhnya terhadap minat beli adalah citra merek dibandingkan dengan kualitas produk. Hal ini dibuktikan dengan nilai Unstandardized coefficient B yang terbesar yaitu 0,356 dan signifikan sebesar 0,000

Dikarenakan keterbatasan waktu dan biaya yang dimiliki oleh peneliti, penelitian ini juga memiliki keterbatasan-keterbatasan. Ada beberapa keterbatasan yang dapat dijadikan sebagai bahan koreksi serta pembelajaran untuk melakukan penelitian yang akan datang. Adapun keterbatasan penelitian ini antara lain:

1. Ruang lingkup penelitian masih kurang luas, karena hanya sebatas masyarakat yang berada diwilayah Jakarta Barat yang sudah pernah menggunakan produk smartphone Xiaomi minimal 3 bulan.

2. Keterbatasan penelitian menggunakan kuesioner yaitu terkadang jawaban yang diberikan oleh responden tidak mewakili keadaan yang sesungguhnya. 
Hasil penelitian ini memberikan implikasi pada peningkatan penjualan produk smartphone Xiaomi untuk:

1. Melakukan peningkatan citra merek dengan media televise untuk melakukan periklanan menyeluruh. sehingga masyarakat dapat tetap mengikuti perkembangan produk yang dimiliki oleh smartphone Xiaomi.

2. Membuat sebuah tempat penerimaan kritik dan saran yang berguna untuk perkembangan kualitas produk smartphone Xiaomi agar dapat sesuai dengan yang diharapkan oleh konsumen sehingga produk smartphone Xiaomi dapat tetap diminati oleh setiap konsumennya. Karena pada dasarnya tahapan produk dapat diminati harus berdasarkan 4 konsep, yaitu: Perhatian (Attention), Ketertarikan (Interest), Keinginan (Desire), dan Tindakan (Action).

\section{DAFTAR PUSTAKA}

Amrullah, Romal, Artika, 2016. Pengaruh Kualitas Produk, harga, dan Citra merek terhadap Keputusan Pembelian Honda Beat. Jurnal Ilmu dan Riset Manajemen, Vol 5, No 7.

Anindita, Rina, dan Hasyim, 2009. Prinsipprinsip dasar metode riset bidang pemasaran. Edisi pertama. Jakarta: UIEU-University Press.

Arikunto, Suharsimi, 2010. Prosedur penelitian suatu pendekatan praktik. Edisi revisi. Yogyakarta: Rineka Cipta.

Artanto, Pramudi, 2016. Pengaruh Kualitas Produk, Citra merek Dan Harga Terhadap Keputusan Pembelian A\&W. Jurnal Ilmu Riset Manajemen, Volume 5, Nomor 4.

Astuti, Nopriani, 2016. Hubungan Citra Merek Dengan Loyalitas Merek Pada Konsumen Mobil PT. Honda Semoga Jaya Samarinda. PSIKOBORNEO, Vol 4.
Durianto, Sugiarto, Widjaja dan Supratikno, 2003. Inovasi Pasar Dengan Iklan Yang Efektif. Jakarta: PT. Gramedia Pustaka Utama.

Ferdinand, Agusty, 2006. Metode Penelitian Manajemen. Edisi 2. Semarang: BP UNDIP.

https://www. statista.com/statistics/430749/chi na-smartphone-shipments-vendormarket-share/, diakses tgl 7 Oktober 2016 Jam 16.10 WIB

Kartajaya, H, 1997. Siasat Memenangkan Persaingan Global. Jakarta: PT. Gramedia Pustaka Utama.

Kodu, Sarini, 2013. Harga Kualitas Produk dan Kualitas Pelayanan Pengaruhnya Terhadap Keputusan Pembelian Mobil Toyota Avanza. Jurnal EMBA, Vol 1, No 3 .

Listyawati, Hastuti, Indri, 2014. Analisis Pengaruh Citra Merek Terhadap Keputusan Pembelian Kartu Simpati di Yogyakarta. JBMA, Vol II, No 1.

Lumanau, Sepang, dan Mandagie, 2014. Iklan dan Citra Merek terhadap Keputusa Pembelian kartu GSM TRI di Manado. Jurnal EMBA, Vol 2, No 3.

Lumintang, dan Jopie, 2015. Analisis Kualitas Produk dan Kualitas Pelayanan terhadap Kepuasan Konsumen pada Holland Bakery Boulevard Manado. Jurnal EMBA, Vol 3, No 1 .

Lupiyoadi, R, 2009. Manajemen Pemasaran Jasa. Edisi 2. Jakarta: Salemba Empat.

Machfoedz, M, 2010. Komunikasi Pemasaran Modern. Cetakan Ketiga. Jakarta: KencanaPrenadaMediaGrup.

Maholtra, K. Naresh, 2005. Riset Pemasaran Pendekatan Terapan. Edisi Keempat. jilid 1. Jakarta: PT. Indeks Kelompok Garamedia.

Nilowardono, dan Ningrum, 2016. Pengaruh Event dan Brand Image Terhadap Minat Beli Produk Rokok Sampoerna A Mild Pada PT. HM Sampoerna 
Area Marketing Surabaya. E-Journal Manajemen Kinerja, Vol 2, No 1.

Oentoro, Deliyanti, 2012. Manajemen Pemasaran Modern. Edisi Kesembilan. Jakarta: Prehalindo.

Randi, 2016. Pengaruh Citra Merek terhadap Minat beli pada makanan Fast Food ayam goreng. JOM FISIP, Vol 3, No 2.

Rangkuti, Freddy, 2004. The Power Of Brands: Teknik Mengelola Brand Equity dan Strategi Pengembangan Merek Analisis Kasus dengan SPSS. Jakarta: PT. Gramedia Pustaka Utama.

Sandjojo, Nidjo, 2011. Metode analisi jalur (path analysis) dan aplikasinya. Cetakan pertama, Jakarta: Pustaka Sinar Harapan.

Sarwono, Jonathan, 2013. 12 Jurus Ampuh SPSS untuk Riset Skripsi. Jakarta: Elexmedia Komputindo Kompas Gramedia.

Schiffman, L.G, dan, Kanuk, L, L, 2008. Perilaku Konsumen. Edisi Ke Tujuh. Jakarta: PT. Indeks Group Media.

Sepang, Massie, dan Joel, 2014. Pengaruh Motivasi, Persepsi Harga, dan Kualitas Produk Terhadap Minat Beli Konsumen Sepeda Motor Matic Merek Yamaha Mio Di Kota Manado. Jurnal EMBA, Vol 2, No 3.

Setiadi, Nugroho J, 2003. Perilaku Konsumen. Jakarta: Kencana Prenada Media Group

Shimp, Terence, 2000. Periklanan Promosi Dan Aspek Tambahan Komunikasi Pemasaran Terpadu. Jilid I Edisi 5. Jakarta: Erlangga.

Simamora, Bilson, 2002. Aura Merek: 7 Langkah Membangun Merek Yang Kuat. Jakarta: PT. Gramedia Pustaka Utama.

Sugiyono, 2010. Statistika untuk penelitian. Cetakan ke-16. Bandung: Alfabeta.
Sunyoto, Danang, 2012. Konsep dasar riset pemasaran dan perilaku konsumen. Yogyakarta: CAPS.

Susanto, A.B, et al., 2004. Value Marketing Paradigma Baru Pemasaran. Jakarta: PT. Mizan Pustaka.

Sutojo, Siswanto, 2004. Membangun Citra Perusahaan. Jakarta: Damar Media Pustaka.

Suwarto, dan Suharto, 2014. Pengaruh Pelayanan, Kualitas Produk, Dan Citra Merek Terhadap Keputusan Pembelian Sepeda Motor Honda Tipe Supra X 125 Dealer Bhineka Motor Di Kota Metero. DERIVATIF, Vol 8 No.1.

Suyanto, 2007. Marketing Strategy top brand Indonesia. Edisi Kesatu. Yogyakarta: Andi.

Swasta, B, 2002. Manajemen Pemasaran, Analisa Perilaku Konsumen. Edisi Pertama. Yogyakarta: BPFE.

Tamaka, Irvandy, 2013. Citra Merek dan Kualitas Produk pengaruhnya terhadap sikap Konsumen pada Produk Daihatsu di PT. Astra Internasional Daihatsu Manado. Jurnal EMBA, Vol 1, No 3.

Tjiptono, Fandi, 2008. Strategi Bisnis Pemasaran. Yogyakarta: Andi.

Tjiptono, Fandi, 2011. Brand Management and Strategy. Yogyakarta: Andi.

Triatmaja, dan Muthohar, 2013. Pengaruh Endorser Ulama Terhadap Sikap dan Minat Beli Konsumen. Jurnal Bisnis dan Ekonomi.

Tumbuan, dan Manoppo, 2014. Citra Merek, Kualitas Produk, dan Promosi Pengaruhnya terhadap Keputusan Pembelian Parfum Excite Oriflame. Jurnal EMBA, Vol 2, No 2.

Widayatmoko, dan Sari, 2011. Pengaruh Marketing Public Relations terhadap Penciptaan Citra Merek Cafe Gran VIA. Jurnal Komunikasi Universitas Tarumanegara. 
Wijaya, H.P, Mohamad, 2013. Promosi, Citra Merek dan Saluran Distribusi pengaruhnya terhadap Keputusan Pembelian Jasa Terminix di kota Manado. Jurnal EMBA, Vol 1, No 4.

Wijaya, Toni, 2011. Manajemen Kualitas Jasa. Cetakan 1. Jakarta: PT. Indeks.
Yoestini, dan Sulistyari, 2012. Analisi Pengaruh Citra Merek, Kualitas Produk, dan Harga Terhadap Minat Beli Produk Oriflame. DipenogoroJournal Of Management, Vol 1, No 1. 